\title{
SOBRE O CONTROLE JURISDICIONAL DA POLÍTICA EXTERNA - NOTAS ACERCA DO CASO BATTISTI NO STF
}

\author{
Daniel Damásio Borges
}

ON JUDICIAL REVIEW OF FOREIGN POLICY - NOTES ABOUT BATTISTI CASE IN THE BRAZILIAN SUPREME COURT

\section{RESUMO}

O PROCESSO DE EXTRADIC̣ÃO CESARE BATTISTI NO STF SUSCITOU MUITAS POLÊMICAS SOBRE OS MAIS DIFERENTES ASPECTOS DO REGIME JURÍDICO APLICÁVEL AOS ESTRANGEIROS NO BRASIL, DE UM MODO GERAL, E SOBRE O PROCESSO DE EXTRADIC̄ÃO, DE MODO PARTICULAR. O FOCO DE ANÁLISE DESTE ARTIGO É MAIS CIRCUNSCRITO: OS FUNDAMENTOS INVOCADOS PELO STF PARA Justificar a margem de escolha do Poder Executivo em EFETUAR OU NÃO A EXTRADIÇÃO, UMA VEZ AUTORIZADO A FAZÊ-LO PELO PRÓPRIO STF. EM ESPECIAL, EM SUA ARGUMENTAÇ̃̃O, O SUPREMO SUgERE A IDEIA DE QUE O PODER EXECUTIVO DISPÕE DA MAIS AMPLA LIBERDADE NA CONDUCĊ̃O DA POLÍTICA EXTERNA E DE QUE ELE NÃO ESTÁ SUJEITO A UM CONTROLE JURISDICIONAL NESSA MATÉRIA. PROCURAR-SE-Á DEMONSTRAR QUE ESSA LINHA ARGUMENTATIVA NÃO ESTÁ DE ACORDO COM O TEXTO CONSTITUCIONAL. ADEMAIS, OUTROS ARGUMENTOS PODERIAM SER UTILIZADOS PARA RESPaldar a deCISÃo do Presidente da República em NĀO EXTRADITAR BATTISTI.

\section{PALAVRAS-CHAVE}

PODER EXECUTIVO; RELAÇÕES INTERNACIONAIS; EXTRADIC̣ÃO; POLÍTICA EXTERNA; CONTROLE JURISDICIONAL.

\begin{abstract}
THE BatTISTI CASE IN THE BRAZILIAN Supreme COURT RAISED MANY CONTROVERSIAL ISSUES ABOUT THE STATUS OF FOREIGNERS IN BRAZIL AND THE EXTRADITION PROCESS IN THE BRAZILIAN LAW. THE FOCUS OF THIS PAPER IS MORE CIRCUMVENTED: THE ANALYSIS OF THE LEGAL REASONS INVOKED BY THE BRAZILIAN SUPREME COURT TO JUSTIFY THE DISCRETION OF THE PRESIDENT TO EXTRADITE OR NOT, AFTER THE AUTHORIZATION OF THE BRAZILIAN SUPREME COURT. MORE PRECISELY, IN ITS LEGAL REASONING, THE BRAZILIAN SuPREME COURT SUgGests that THE PRESIDENT DISPOSES OF A GREAT MARGIN OF DISCRETION IN FOREIGN POLICY AND THAT MATTERS RELATED TO THIS SUBJECT LIE BEYOND JUDICIAL COGNIZANCE. WE WILL TRY TO DEMONSTRATE THAT THIS LEGAL REASONING IS NOT IN ACCORDANCE WITH THE BRAZILIAN CONSTITUTION. MOREOVER, OTHER ARGUMENTS COULD BE RAISED TO JUSTIFY THE BRAZILIAN PRESIDENT'S DECISION TO NOT EXTRADITE BATTISTI.
\end{abstract}

\section{KEYWORDS}

EXECUTIVE POWER; INTERNATIONAL RELATIONS; EXTRADITION; FOREIGN POLICY; JUDICIAL REVIEW.

\section{INTRODUÇÃO}

O processo de extradição do italiano Cesare Battisti no Supremo Tribunal Federal (STF) mobilizou a opinião pública brasileira e engendrou posições polarizadas no meio jurídico nacional sobre os seus mais diferentes aspectos. ${ }^{1}$ Ele suscitou muitas polêmicas sobre as várias facetas do direito brasileiro sobre o regime jurídico aplicável aos estrangeiros, de um modo geral, e sobre o processo de extradição, de modo particular. Questões como o conceito de refugiado, o poder discricionário do Ministro 
da Justiça em acordar essa condição a um estrangeiro, a noção de crime político foram alguns dos temas controversos suscitados por esse célebre caso.

O propósito do presente artigo não é o de tratar de todos esses aspectos da decisão do STF. A bem dizer, em razão da complexidade desse litígio, cada qual merece uma análise pormenorizada à parte. Por esse motivo, a finalidade dessa contribuição é bem mais modesta ao focalizar apenas um dos pontos da decisão do STF. Trata-se do entendimento da mais alta jurisdição brasileira, segundo o qual o Presidente da República poderá se negar a extraditar um estrangeiro, mesmo após a autorização do STF e apesar da existência de obrigações nesse sentido previstas em um tratado de extradição entre o Brasil e o Estado que requer a extradição. Mais precisamente, o objeto deste artigo é análise crítica da argumentação desenvolvida pelos Ministros do STF para conferir esse poder ao Presidente da República, notadamente no que se refere à titularidade do exercício da soberania externa do Estado brasileiro. Na leitura do STF, a soberania externa refere-se aos atos do Estado brasileiro no campo das relações e da política internacionais.

Para melhor explicitar essa questão, convém rememorar, brevemente e em largos traços, os principais pontos do caso Cesare Battisti no STF. Em verdade, o Supremo proferiu dois acórdãos que se referem a esse litígio: o primeiro diz respeito ao pedido de extradição feito pela Itália ${ }^{2}$ e o segundo concerne à reclamação da Itália que argumentava que o primeiro acórdão não havia sido cumprido pelo Presidente da República. ${ }^{3}$ De início, cabe descrever o acórdão sobre o pedido de extradição.

Com base no tratado de extradição entre Brasil e Itália de 17 de outubro de 1989, a Itália requereu ao Brasil a extradição executória de Battisti. O pedido italiano era fundado em sentença condenatória da Corte de Apelações de Milão, transitada em julgado na Corte de Cassação, por quatro crimes de homicídio: um contra um agente penitenciário, outro contra um agente da polícia e dois outros contra comerciantes. A autoria desses crimes foi sempre negada por Battisti, que atribuiu essas condenações a perseguições políticas de que seria vítima e ao desrespeito ao seu direito à ampla defesa.

Em consonância com o que prescreve o direito extradicional brasileiro, o pedido do governo italiano foi levado à apreciação do STF. No transcorrer do processo de extradição na alta jurisdição brasileira, Battisti solicitou ao Comitê Nacional para os Refugiados (Conare) a concessão do status de refugiado. Todavia, essa entidade negou-lhe tal condição, o que o conduziu a interpor um recurso administrativo perante o Ministro da Justiça. ${ }^{4}$ O recurso foi provido pelo Ministro da Justiça, o que valeu a Battisti a condição de refugiado.

Após a concessão do refúgio, a defesa de Battisti pediu ao STF que julgasse prejudicado o pedido de extradição em virtude do artigo 33 da Lei n. 9.474/97: "O reconhecimento da condição de refugiado obstará o seguimento de qualquer pedido de extradição baseado nos fatos que fundamentaram a concessão de refúgio”. 
Esse pleito da defesa foi, todavia, rejeitado pelo STF. O motivo da rejeição foi o entendimento de que o Ministro da Justiça havia praticado um ato ilegal ao outorgar a Battisti o status de refugiado. De acordo com a corte brasileira, havia uma ausência de correspondência entre os pressupostos legais para a outorga da concessão do refúgio - notadamente os fundados temores de perseguição por motivos de opiniões políticas ${ }^{5}$ - e as circunstâncias factuais desse litígio. Segundo a Corte, a concessão do refúgio a Battisti era ilegal e ineficaz por não atender os requisitos da lei brasileira. Por essa razão, prosseguiu o STF, o ato administrativo do Ministro da Justiça em exame não poderia obstar o seguimento do processo de extradição.

O STF foi mais além. Os crimes atribuídos a Battisti não poderiam ser considerados políticos, motivo pelo qual a alta jurisdição brasileira autorizou a sua extradição.

Nessa altura, surgiu a questão de saber se o Presidente da República estaria obrigado a extraditar Battisti, visto que o STF havia deferido o pedido de extradição e haja vista as disposições do tratado de extradição entre o Brasil e a Itália. Sobre o tema, os ministros da Suprema Corte mostraram-se muito divididos, o que engendrou um vivo debate entre eles. Os Ministros Gilmar Mendes, Ellen Gracie, Ricardo Lewandowski e Cezar Peluso votaram pela obrigatoriedade da entrega do extraditando por parte do Chefe do Poder Executivo, após deferimento da extradição pelo STF. Por outro lado, os Ministros Joaquim Barbosa, Marco Aurélio, Cármen Lúcia e Carlos Britto entenderam que tal ato era de competência discricionária do Presidente da República. Em uma posição intermediária, o Ministro Eros Grau estimou que o Presidente da República tem o dever de agir nos termos do tratado de extradição entre o Brasil e a Itália, fazendo, contudo, a seguinte ressalva: o cumprimento do tratado de extradição entre o Brasil e a Itália não significa dizer que o deferimento da extradição pelo STF vincule o Presidente da República ou ainda que o Presidente da República esteja obrigado a executar a extradição nesse caso concreto.

Após a publicação do primeiro acórdão do STF, o Presidente da República negou a extradição de Cesare Battisti. ${ }^{6}$ Essa decisão baseou-se no parecer da Advocacia-Geral da União n. 17/2000 de autoria do Consultor da União Arnaldo Sampaio de Moraes Godoy, aprovado pelo Advogado-Geral da União Substituto. ${ }^{7}$ O parecer invocou a letra "f" de número 1 do artigo $3^{\circ}$ do tratado de extradição entre o Brasil e a Itália para respaldar a recusa da extradição. Tal disposição convencional traz uma exceção às obrigações recíprocas de extraditar. Ela prevê que a extradição não será concedida "se a Parte requerida tiver razões ponderáveis para supor que a pessoa reclamada será submetida a atos de perseguição e discriminação por motivo de raça, religião, sexo, nacionalidade, língua, opinião política, condição social ou pessoal; ou que sua situação possa ser agravada por um dos elementos antes mencionados [...]”. A Advocacia-Geral da União entendeu que o caso Battisti amoldava-se a essa exceção. Nesse passo, salientou-se o contexto político em torno do qual girava esse pedido, especialmente a polarização ideológica, o acirramento de paixões e o clamor público que ele havia gerado 
na sociedade italiana. Ademais, fez-se referência à condição pessoal do Battisti, sobretudo a sua intensa participação política em um momento conturbado da história italiana. Esse conjunto de fatores levou a Advocacia-Geral da União a entender que o extraditando poderia sofrer algum tipo de agravamento de sua situação em virtude de sua condição pessoal.

Diante dessa recusa do Poder Executivo fundada nos argumentos acima aludidos, a República Italiana ajuizou uma reclamação alegando que ele não havia cumprido a decisão do STF já analisada. Para a Itália, o Presidente da República não havia respeitado a determinação do Supremo de cumprir o tratado de extradição entre Brasil e Itália, pois o caso Battisti não se enquadrava na letra "f”" de número 1 do artigo $3^{\circ}$ de tal tratado. Os advogados de Battisti, por sua vez, pleitearam o relaxamento de sua prisão.

É essa fase do caso Battisti que nos interessa mais de perto e que conduziu o STF a proferir uma segunda decisão. Ao final, a Corte Suprema julgou que a reclamação não era cabível e determinou a soltura do extraditando. $\mathrm{O}$ aspecto mais proeminente da decisão são as razões invocadas para justificá-la. Antes mesmo de se pronunciar sobre a pertinência da tese italiana exposta na reclamação, a Alta Corte brasileira analisou se, em abstrato, o ato do chefe do Poder Executivo de não extraditar era sindicável pelo Poder Judiciário. O Supremo rejeitou essa possibilidade ao afirmar que o ato de extradição faz parte do exercício da soberania externa do Estado brasileiro e que tal soberania é exercida apenas pelo Chefe de Estado. O STF não conheceu, assim, da reclamação italiana.

Nos termos do acórdão da Reclamação 11.243, redigido pelo Ministro Luiz Fux,

7. A Soberania Nacional no plano transnacional funda-se no princípio da independência nacional, efetivada pelo Presidente da República, consoante suas atribuições previstas no art. 84, VII e VIII, da Lei Maior. 8. A soberania, dicotomizada em interna e externa, tem na primeira a exteriorização da vontade popular (art. 14 da CRFB) através dos representantes do povo no parlamento e no governo; na segunda, a sua expressão no plano internacional, por meio do Presidente da República. [...] 18. A Reclamação por descumprimento de decisão ou por usurpação de poder, no caso de extradição, deve considerar que a Constituição de 1988 estabelece que a soberania deve ser exercida, em âmbito interno, pelos três Poderes (Executivo, Legislativo e Judiciário) e, no plano internacional, pelo Chefe de Estado, por isso que é insindicável o poder exercido pelo Presidente da República e, consequentemente, incabível a Reclamação, porquanto juridicamente impossível submeter o ato presidencial à apreciação do Pretório Excelso. 
Esses escritos sugerem a ideia de que o exercício da soberania pelo Estado brasileiro no plano internacional seria da alçada exclusiva do Presidente da República, ao contrário do que sucede com a soberania interna.

O raciocínio seguido pela maioria dos ministros do STF conduz a acordar ao chefe do Poder Executivo uma margem de ação demasiadamente extensa em um assunto da mais alta relevância e a enfraquecer o controle do exercício dessa política. Além disso, como se verá adiante, esse tipo de fundamentação era dispensável para validar a permanência de Battisti em território nacional.

Dois motivos, em especial, parecem-nos determinantes para criticar essa linha de pensamento. Em primeiro lugar, na disciplina geral da soberania externa brasileira, a CF estabeleceu uma repartição de competências entre os poderes da República e prescreveu princípios a serem por eles obrigatoriamente observados. Desse modo, a fundamentação do STF contraria os princípios gerais que regem o exercício da soberania externa pelo Estado brasileiro (item 1). Ademais, justamente em matéria de extradição, a CF foi particularmente cuidadosa em não concentrar todos os poderes no Presidente da República, de modo a assegurar o cumprimento de princípios constitucionais que regem as relações internacionais do Brasil. O fundamento do aludido acórdão do STF não está, portanto, em consonância com as normas brasileiras sobre o próprio processo de extradição (item 2).

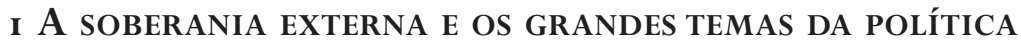 \\ INTERNACIONAL: A NECESSIDADE DO CONCURSO DOS DIFERENTES ÓRGÃOS DO ESTADO BRASILEIRO}

Uma das disposições da CF mais citadas no caso Battisti é o artigo 84, VII e VIII: "Compete privativamente ao Presidente da República: [...]VII - manter relações com Estados estrangeiros e acreditar seus representantes diplomáticos; VIII - celebrar tratados, convenções e atos internacionais, sujeitos a referendo do Congresso Nacional”.

Não restam dúvidas de que esses dois incisivos conferiram ao Poder Executivo certa primazia na condução da política externa brasileira. A propósito, com fulcro nesse artigo da CF, o Presidente da República editou o Decreto n. 7.304, de 22 de setembro de 2010, o qual aprova a Estrutura Regimental do Ministério das Relações exteriores. De acordo com o artigo 54 de tal regimento, as Missões Diplomáticas permanentes, que compreendem Embaixadas, Missões e Delegações Permanentes junto a organismos internacionais, são criadas e extintas por decreto e têm natureza e sede fixadas no ato de sua criação. Ainda nesse sentido, o artigo 60 do mesmo regimento preceitua que os consulados-gerais, os consulados e vice-consulados são criados ou extintos por decreto, que lhes fixa a categoria e a sede.

Desse modo, as decisões sobre embaixadas e consulados, os quais são instrumentos indispensáveis da política externa brasileira, são da alçada da Presidência da República. 
É por meio das embaixadas, por exemplo, que se aprofundam as relações bilaterais entre os Estados, pois elas permitem que estes, de modo contínuo e regular, troquem informações entre si e negociem acordos ou entendimentos sobre os mais diferentes temas de interesse comum.

O referido decreto ainda prescreve, em seus artigos 76 e 77, que os chefes de missão diplomática permanente, os chefes de missão ou delegação permanente junto a organismo internacional e os titulares dos consulados-gerais, consulados e vice-consulados serão nomeados pelo Presidente da República.

Como partes integrantes da Administração Federal, o corpo diplomático brasileiro está sob a "direção superior" do Presidente da República. ${ }^{8}$ Os funcionários do Ministério das Relações Exteriores devem seguir, em última análise, as orientações do Presidente da República.

É, igualmente, o Presidente da República que recebe dos chefes de Missão diplomática de Estados estrangeiros as cartas credenciais desses últimos. ${ }^{9}$ Essas cartas constituem o documento oficial em que constam os poderes de representação do chefe da missão diplomática de falar em nome de seu Estado. A circunstância de esse documento formal ser direcionado ao Presidente da República bem demonstra que ele representa o Estado brasileiro perante as nações estrangeiras.

Desse modo, as observações de Elisabeth Zoller sobre a função do Presidente da República na França nas relações com os países estrangeiros aplicam-se ao direito brasileiro das relações exteriores. ${ }^{10}$ É por meio do Presidente da República que o Brasil estabelece relações com os Estados estrangeiros, pois é ele quem nomeia os representantes do Brasil junto a tais países e é ele, também, quem recebe as credenciais dos diplomatas estrangeiros no Brasil.

Ainda consoante a Constituição Federal, nas negociações internacionais sobre a celebração dos tratados internacionais, é o Presidente da República o órgão competente para representar o Brasil. Ele pode delegar essa função a seus ministros ou a embaixadores plenipotenciários. A posição brasileira na confecção desses documentos internacionais será aquela definida pelo chefe do Poder Executivo. Incumbirá a ele decidir, em última análise, se o Brasil apresentará, rejeitará ou adotará modificações ao texto negociado com os seus pares da comunidade internacional. A ele caberá dar a anuência do Estado brasileiro acerca do texto fruto das negociações. É a partir dessa anuência dos Estados negociadores que o texto do tratado é considerado autêntico e definitivo, o que não significa dizer, como se verá adiante, que as obrigações nele previstas vinculem tais Estados.

Conforme afirma José Francisco Rezek, essas atribuições constitucionais deferem ao Presidente da República o poder de ditar a dinâmica da política exterior brasileira. Cabe-lhe, assim, estabelecer e romper as relações diplomáticas com os Estados, decidir por uma postura de maior aproximação ou de maior distanciamento em relação a esse ou aquele Estado, aceitar ou recusar convites para conferências internacionais, tomar a 
iniciativa de propor reuniões de cúpula entre chefes de Estado e defender a posição brasileira nas organizações internacionais (REZEK, 1984, p. 317).

O poder de iniciativa e de impulsão da política externa brasileira de que dispõe o chefe do Poder Executivo não se restringe a esses artigos. O artigo 84 da CF elenca dentre o rol das competências privativas do Presidente da República: a) exercer o comando supremo das Forças Armadas (inciso XIII); b) declarar guerra, no caso de agressão estrangeira, autorizado pelo Congresso Nacional ou referendado por ele, quando ocorrida no intervalo das sessões legislativas, e nas mesmas condições, decretar, total ou parcialmente, a mobilização nacional (inciso XIX); c) celebrar a paz, autorizado ou com o referendo do Congresso Nacional (inciso XX); e d) permitir, nos casos previstos em lei complementar, que forças estrangeiras transitem pelo território nacional ou nele permaneçam temporariamente (inciso XII).

O Presidente da República controla e comanda o uso das forças armadas, o último recurso de que os Estados fazem valer nas relações internacionais. Essas disposições são tanto mais significativas quanto elas conferem, em última análise, o poder de vida e de morte ao Presidente da República. Como bem salientou Elisabeth Zoller, quem detém essa prerrogativa é titular do poder supremo (ZOLLER, 1992, p. 66). Nunca é demais ressaltar o impacto das operações militares para a política externa do Estado e para a sua própria vida interna. ${ }^{11}$

No entanto, essa primazia do Poder Executivo (BADIN; FRANÇA, 2010) na condução da vida internacional do Brasil não quer dizer, de nenhum modo, exclusividade e muito menos ausência de controle em seu exercício. ${ }^{12}$ A CF assegura tanto ao Legislativo quanto ao Judiciário funções de grande relevo na execução dessa política pública.

Mesmo no que concerne à representatividade externa do Estado brasileiro, a CF não a trata como o domínio exclusivo do Presidente da República. Segundo o artigo 52, IV, da CF, é da competência privativa do Senado Federal a aprovação prévia, por voto secreto, após arguição em sessão secreta, a escolha dos chefes de missão diplomática de caráter permanente. Desse modo, a voz do Senado Federal é determinante na escolha dos representantes do Brasil perante as nações estrangeiras, ainda que eles sejam nomeados pelo Presidente da República.

No que respeita aos tratados internacionais, o artigo 49, I, da CF determina que é da competência exclusiva do Congresso Nacional resolver definitivamente sobre tratados, acordos ou atos internacionais que acarretem encargos ou compromissos gravosos ao patrimônio nacional. Assim, para que o Estado brasileiro manifeste o seu consentimento definitivo em se obrigar a cumprir um tratado que acarrete encargos ou compromissos ao patrimônio nacional, é indispensável a aprovação do Congresso Nacional. Sem o concurso do Poder Legislativo, nesse caso, o Presidente da República não poderá ratificar esse tratado.

Essa disposição constitucional é um poderoso instrumento do controle parlamentar sobre a política externa posta em prática pelo Poder Executivo. Os tratados 
internacionais são um dos principais meios de consecução dessa política, pois eles podem criar obrigações jurídicas interestatais sobre alianças militares e cooperação econômica. Ao não dar o seu assentimento a um tratado negociado pelo Poder Executivo, o Parlamento censura a política externa desse último e impede que o Brasil assuma obrigações jurídicas que ele considera contrárias ao interesse nacional. $\mathrm{O}$ Parlamento tem, assim, uma participação fundamental na formação da vontade do Estado brasileiro na assunção de obrigações perante a comunidade internacional, que, convém frisar, é um dos elementos primordiais do exercício da soberania externa de um Estado. ${ }^{13}$

Em outro tema da disposição de tal soberania - a paz e a guerra -, o Congresso Nacional tem relevantes atribuições. Nos termos do artigo 49, II, da CF, incumbe ao Congresso Nacional autorizar o Presidente da República a declarar guerra, a celebrar a paz, a permitir que forças estrangeiras transitem pelo território nacional ou nele permaneçam temporariamente, ressalvados os casos previstos em lei complementar. Assim, o fato de as forças armadas estarem sob o comando do Presidente da República não o exonera da obrigação de pedir ao Congresso Nacional a autorização para desencadear um conflito bélico com outros Estados ou a ele pôr fim.

O inciso XIV do mesmo artigo defere ao Parlamento a competência para aprovar iniciativas do Poder Executivo referentes a atividades nucleares. Desse modo, em um tópico tão sensível da defesa nacional, o Poder Executivo deve obter, também, a aprovação parlamentar.

Deve-se, ainda, referir às leis aprovadas pelo Congresso Nacional que dizem respeito a esse assunto. A Lei Complementar n. 80, de $1^{\circ}$ de outubro de 1997, estabelece um rol bem circunscrito de circunstâncias em que o trânsito ou a permanência de forças estrangeiras em território nacional prescinde da autorização do Congresso Nacional. Ela prescreve requisitos a serem observados quando da permanência ou trânsito dessas forças estrangeiras, a exemplo da expressa declaração da sua finalidade.

A Lei n. 2.953, de 17 de novembro de 1956, condiciona o envio de forças armadas para fora do território nacional, sem declaração de guerra e em cumprimento das obrigações assumidas pelo Brasil como membro de organizações internacionais ou em virtude de outros tratados, à autorização do Congresso Nacional. Os envios de contingente brasileiro para a Missão das Nações Unidas no Timor Leste e para a Missão de Estabilização das Nações Unidas no Haiti foram precedidos da aprovação parlamentar por meio de decreto legislativo. ${ }^{14}$ Portanto, o emprego das forças armadas brasileiras deve ser autorizado pelo Congresso Nacional, ainda que não haja uma guerra declarada com um Estado estrangeiro, como no caso das missões de paz da ONU.

Por fim, cumpre notar que a condução da política externa brasileira pelo Poder Executivo, como toda a ação administrativa desse último, está sujeita à fiscalização legislativa. Aplica-se, no caso, o inciso X do artigo 49 da CF, segundo o qual o Congresso tem a prerrogativa de fiscalizar e controlar, diretamente, ou por qualquer de 
suas casas, os atos do Poder Executivo. O Parlamento poderá, assim, convocar o Ministro das Relações Exteriores para prestar informações sobre a política externa ou ainda criar Comissões Parlamentares de Inquérito atinentes a esse assunto (artigo 58, $\S 1^{\circ}$, II, e $\S 3^{\circ}$ ). Nos Estados Unidos, por exemplo, tais comissões tiveram amplo alcance político, como aquela que investigou o escândalo Irã-Contras.

Quanto ao Poder Judiciário, a sua atuação abrange indubitavelmente aspectos da política externa brasileira. A constitucionalidade das obrigações assumidas pelo Brasil perante a comunidade internacional por meio de tratados está sob o crivo do STF. Um tratado internacional já foi inclusive objeto de uma ação direta de inconstitucionalidade, a qual teve por objeto a Convenção n. 158 da OIT sobre o término da relação de trabalho por iniciativa do empregador. Na ementa do acórdão dessa ação, afirma-se explicitamente que o Poder Judiciário, fundado na supremacia da Constituição, é competente para efetuar o exame de constitucionalidade dos tratados, quer em sede de fiscalização abstrata, quer no âmbito do controle difuso. ${ }^{15}$ Há subjacente a essa prerrogativa do STF um autêntico controle judicial da política externa brasileira. Como se afirmou, os tratados fazem parte de tal política. Julgar procedente uma ação acerca da inconstitucionalidade de um tratado, é censurar as negociações diplomáticas entabuladas pelo Poder Executivo e a sua aprovação pelo Poder Legislativo.

A própria denúncia de tratados já foi objeto da Ação Direta de Inconstitucionalidade 1.625. Na espécie, questiona-se a constitucionalidade do Decreto Federal n. 2.100/96 do Presidente da República, por meio do qual o chefe do Poder Executivo comunicou oficialmente que a Convenção em apreço deixaria de ser cumprida no Brasil a partir de 20 de novembro de 1997 em razão da sua denúncia junto à OIT. Tal decreto não foi precedido da anuência parlamentar. Até o presente momento, quatro ministros manifestaram seu voto. De um lado, o Ministro Nelson Jobim considerou constitucional o decreto presidencial, por ser o chefe do Poder Executivo o órgão competente para denunciar as convenções de que o Brasil seja parte. De outro lado, os Ministros Maurício Corrêa, Carlos Britto e Joaquim Barbosa entenderam a ação de inconstitucionalidade procedente, pois ao Congresso Nacional incumbe (artigo 49, I, da $\mathrm{CF} / 88$ ) resolver definitivamente sobre os tratados, inclusive no que diz respeito à sua denúncia. ${ }^{16}$ A leitura da CF que até agora prevaleceu, nesse caso, é justamente no sentido de aprofundar o controle da política externa conduzida pelo Presidente da República, ao condicionar a denúncia de um tratado à anuência parlamentar.

Também não se deve olvidar que o Poder Judiciário, com frequência, interpreta e aplica os tratados internacionais, uma vez devidamente integrados ao sistema jurídico brasileiro. Isso gera efeitos para as relações diplomáticas do Brasil com os Estados-partes dessas convenções. Na Arguição de Descumprimento de Preceito Fundamental 1722, a Ministra Ellen Gracie chamou a atenção para a necessidade da correta aplicação pelo Poder Judiciário da Convenção de Haia de 1980 sobre os aspectos civis do sequestro internacional de crianças. Caso isso não ocorresse, prosseguiu a ministra, havia o 
risco de comprometer as relações do Brasil com os Estados-partes da convenção. ${ }^{17} \mathrm{O}$ STJ também já proferiu decisões muito delicadas para os Estados com os quais o Brasil mantém relações diplomáticas, a exemplo da imunidade de jurisdição de suas representações diplomáticas em território brasileiro. ${ }^{18} \mathrm{O}$ modo pelo qual os juízes brasileiros aplicam o direito internacional não deixa de ser uma modalidade de exercício da soberania externa brasileira, pois essas decisões se projetam nas relações do Brasil com outros Estados.

Outro ponto que merece nossa atenção são os princípios constitucionais que devem reger a inserção e a participação do Brasil na sociedade internacional. Com efeito, uma das inovações da Constituição de 1988 (SANCHEZ; SILVA; CARDOSO; SPECIE, 2006) foi estabelecer os valores e objetivos que devem orientar a conduta brasileira nas relações internacionais, dentre os quais estão a prevalência dos direitos humanos (artigo $4^{\circ}$, II, da CF). É notável que o artigo $4^{\circ}$ da CF não se limita a mencionar os direitos humanos, pois preceitua que esse valor deve ter preponderância, o que indica a ordem de prioridades nas interações do Brasil com as nações estrangeiras.

Em suma, os temas de política externa - inclusive as grandes opções nesse campo como a assunção de obrigações internacionais e o desencadeamento de um conflito armado internacional - não são apanágio do Poder Executivo. Não é, assim, somente o Poder Executivo que exerce a soberania externa brasileira, ou seja, que determina as relações do Brasil com o mundo exterior. Mais do que isso, para além das regras de repartição de competências, a CF determina normas substantivas a pautarem a conduta do Estado brasileiro nas relações exteriores.

É bem verdade que muitos argumentos já foram expostos para conceder a mais ampla autonomia ao chefe do Poder Executivo nesse campo. É conhecida a leitura das relações internacionais que enfatiza a política do poder, segundo a qual os Estados devem a sua existência e a segurança não ao direito internacional ou a qualquer outra norma, mas apenas às suas próprias forças e as de seus aliados. Nessa ordem de ideias, deve-se ter presente no horizonte a deflagração armada entre os Estados, circunstância em que a independência e a existência mesma dos Estados mais frágeis estão sempre sob risco (ARON, 2002, p. 153-203). Por esses motivos, seria prudente atribuir ao Chefe do Poder Executivo a mais ampla discrição para defender os interesses nacionais - notadamente a segurança e a independência nacional - em um contexto internacional em que elas estão constantemente ameaçadas. Somente essa centralização de poderes em um único órgão seria capaz de dotar o Estado da unidade de ação e de comando necessários para assegurar a independência nacional e a integridade territorial. Não é, assim, de surpreender que no direito constitucional comparado o Poder Executivo desfrute de uma margem de ação maior nas relações internacionais do que em qualquer outro setor da atividade administrativa (ZOLLER, 1992, p. 29-91). ${ }^{19}$

Em que pesem esses argumentos, é forçoso reconhecer que a ideia de um poder ilimitado do Presidente da República na seara internacional não foi adotada pela 
Constituição Federal. Há, sim, um compartilhamento de competências entre os poderes no que tange às relações exteriores. Existem, sim, princípios que o Presidente da República deve obrigatoriamente respeitar nessa seara. Essas normas tornam efetivos princípios caros ao direito constitucional brasileiro, como o equilíbrio de poderes, o Estado democrático de direito e o controle do exercício do poder. De acordo com a CF, a decisão de desencadear um conflito armado não é a decisão de apenas uma pessoa, mas deve ser fruto de um debate e de uma deliberação democrática na assembleia dos representantes do povo. Nessa perspectiva, os princípios constitucionais reforçam e não diminuem a posição do Brasil no estrangeiro. O controle jurisdicional dos atos do Poder Executivo na seara internacional encontra-se, assim, plenamente justificado.

Isso não impede, obviamente, que seja reconhecida certa margem de discricionariedade ao Presidente da República na condução de determinados assuntos nas relações internacionais. Mas defender essa margem de discricionariedade é algo inteiramente diverso da ausência de controle jurisdicional dos atos do Presidente da República.

Esse modo de enquadrar juridicamente a atuação externa do Estado brasileiro assume especial relevo no contexto atual em que a soberania interna e a externa do Estado estão estreitamente imbricadas. ${ }^{20}$ Os temas das negociações diplomáticas entre os Estados não se resumem mais ao direito da paz e da guerra, para repetir uma formulação frequente dos cursos de direito internacional público de Haia no início do século XX. Tais tratativas abordam hoje outros assuntos que estão, também, no cerne do pacto social nacional, como a proteção dos direitos humanos e do meio ambiente. $\mathrm{O}$ foco das convenções dos direitos humanos é muito menos a disciplina das relações entre os Estados que assegurar direitos subjetivos aos indivíduos em face dos Estados a cuja jurisdição estão submetidos. ${ }^{21}$ Levando-se em consideração esse fato, a vigilância sobre a disposição da soberania externa brasileira deve ser reforçada e não diminuída, inclusive no que se refere ao seu controle jurisidicional.

Essa vigilância, como se verá adiante, já ocorre com particular acuidade em uma modalidade particular de exercício de soberania externa: a extradição.

\section{A SOBERANiA EXTERnA E A EXTRAdiÇÃo:}

A FUnÇÃo CRUCIAL do PODER JUdiCIÁRIO

A recorrência da alusão à palavra soberania no julgamento de Battisti não é de surpreender. Deveras, o instituto da extradição está intimamente relacionado a essa noção. Segundo a definição precisa do Ministro Ricardo Lewandowiski, a extradição "constitui um processo formal mediante o qual um Estado (Estado requerido), entrega uma pessoa a outro Estado (Estado requerente), para o fim de submetê-la a um processo penal ou à execução de uma sentença criminal”. ${ }^{22}$

A extradição insere-se, assim, no quadro das relações entre dois Estados igualmente soberanos, pois constitui um ato de colaboração entre eles na repressão à criminalidade. 
Ela está estreitamente relacionada ao caráter territorial da soberania estatal. Nenhum Estado, sob pena de incorrer em uma grave violação do direito internacional, pode agir no território de outro, exceto se esse último tenha dado o seu consentimento nesse sentido. Quando um indivíduo processado penalmente ou já condenado pela justiça de um determinado Estado foge para o território de outro, as autoridades policiais do primeiro Estado não podem prender tal indivíduo no território do segundo Estado. ${ }^{23}$ Quando um estrangeiro se encontra no território de um determinado Estado, ele está submetido à soberania desse último, ainda que tenha fugido da justiça de seu país. Isso decorre do princípio da soberania territorial, segundo o qual o Estado exerce sobre esse espaço geográfico a integralidade de seus poderes, com a exclusão da atuação das autoridades de qualquer outro país estrangeiro. É por esse motivo que o pedido de extradição é o único modo admitido pelo direito internacional para que o Estado exerça o seu jus puniendi sobre o indivíduo que se encontra no território de outro.

A existência de tal pedido de extradição não significa, necessariamente, que ele será atendido. O Estado requerente fica sempre na dependência da anuência do Estado requerido para efetivar esse ato de cooperação penal. Como afirma Philippe Richard, a apreciação do pedido por parte do Estado requerido é um real ato de soberania (RICHARD, 1988, p. 656). ${ }^{24}$ É, assim, o Estado requerido que decidirá se todas as condições que ele entende cabíveis estão reunidas para que o pedido de extradição seja aceito.

Não restam dúvidas, portanto, de que a análise do pedido de extradição pelo Estado brasileiro constitui um exercício de soberania externa, isto é, um ato de soberania que se projeta nas relações internacionais. O ponto controverso, a esse propósito, diz respeito apenas ao papel a ser desempenhado por cada órgão do Estado brasileiro no processo de extradição.

O direito extradicional brasileiro enquadra juridicamente como essa soberania externa do Estado brasileiro deve ser exercida. Um dos principais requisitos é a análise pelo STF do pedido de extradição. Nos termos do artigo 83 da Lei n. 6.815, de 19 de agosto de 1980 - lei que define a situação jurídica do estrangeiro no Brasil -, "nenhuma extradição será concedida sem prévio pronunciamento do Plenário do STF sobre sua legalidade e procedência, não cabendo recurso da decisão”. O artigo 102, I, “g”, da Constituição Federal preceitua que compete ao STF, precipuamente, a guarda da Constituição, cabendo-lhe processar e julgar, originariamente a extradição solicitada por Estado estrangeiro. Por conseguinte, uma vez recebido o pedido de extradição pelo Poder Executivo brasileiro, tal pleito deverá ser encaminhado ao Supremo Tribunal Federal.

O direito extradicional brasileiro vai mais além. Ele estabelece alguns princípios que devem pautar o julgamento do pedido de extradição pelo STF. Dentre o rol dos direitos e garantias fundamentais estabelecidos pela Constituição, figura a recusa da 
extradição de estrangeiro por crime político ou de opinião (artigo $5^{\circ}$, LII, da CF). De acordo com o artigo 77, II e VIII, da Lei n. 6.815, de 19 de agosto de 1980, não se concederá a extradição quando o fato que motivar o pedido não for considerado crime no Brasil ou no Estado requerente e quando o extraditando houver de responder, no Estado requerente, perante Tribunal ou Juízo de exceção.

No julgamento dessas exigências que devem ser atendidas pelo pedido de extradição, o STF já deu provas de que ele está atento a elas. No processo de extradição que a China formulou de seu nacional Quian Hong, ${ }^{25}$ o relator, Ministro Celso de Mello, ressaltou que o Estado requerente é obrigado a identificar, com clareza e precisão, os elementos definidores do crime que é atribuído ao extraditando. Ademais, ressaltou que o STF não deve autorizar a extradição se o Estado requerente não assegurar ao extraditando a garantia do devido processo legal. Essas foram algumas das razões que conduziram os ministros do STF a indeferirem, por unanimidade, o pleito chinês.

Em seu voto, o Ministro Celso de Mello bem realçou duas considerações que podem estar em conflito em um processo de extradição: de um lado, a necessidade de os Estados cooperarem na repressão penal dos delitos comuns; de outro lado, o dever de velar pelo respeito dos direitos fundamentais do súdito estrangeiro. Mais do que isso, o Ministro Celso de Mello identificou qual dessas duas considerações deve preponderar. Em suas palavras, o Estado brasileiro assumiu o gravíssimo dever de sempre fazer prevalecer os direitos humanos, obrigação prevista no artigo $4^{\circ}$, II, da Constituição Federal.

Conclui-se, assim, que o Supremo Tribunal Federal, ao apreciar o pedido de extradição, opera uma escolha dos valores que devem guiar a política externa brasileira. Isso é tanto mais verdadeiro que caso o STF rejeite o pedido, o Presidente da República não poderá efetuar a extradição.

Ao fazer esse julgamento, o STF não está submetido ou vinculado a nenhuma autoridade externa, ou seja, a nenhum órgão de qualquer outro Estado estrangeiro. Nesse sentido, ele encarna e efetiva a independência nacional nas relações internacionais. Desse modo, contrariamente ao que sugere o acórdão da Reclamação 11.243, a independência nacional não é apenas encarnada pelo Presidente da República.

Esse poder atribuído ao STF de rejeitar a extradição é facilmente compreensível. A extradição coloca em causa a liberdade individual, visto que ela significa a prisão de um indivíduo pelo Estado requerido e a sua entrega ao Estado requerente com vistas a um julgamento penal ou a execução da pena. Ora, o guardião por excelência dessa liberdade é o Poder Judiciário. ${ }^{26}$ Caso o poder de extraditar não passasse pelo crivo do Poder Judiciário e fosse atribuição exclusiva das autoridades administrativas, haveria um claro risco de barganhas políticas entre os Estados em prejuízo da defesa dos direitos e garantias fundamentais dos estrangeiros. Imagine-se, por exemplo, a situação em que o Estado requerente ofereça ao Estado requerido vantagens econômicas, cooperação militar ou apoio diplomático nas organizações internacionais em contrapartida da entrega da extraditando. Tal situação não é de todo improvável, haja vista a prioridade 
que os Estados requerentes atribuem para essa entrega. A necessidade do prévio pronunciamento de um tribunal independente e imparcial sobre os fundamentos do pedido de extradição impõe um substancial limite a esse tipo de tratativas diplomáticas e, por conseguinte, ao poder do presidente da República na política internacional. Como bem observou o Ministro Carlos Britto, "é preciso que o STF atue em matéria extradicional para impedir que duas soberanias estatais eventualmente conluiadas esmaguem o indivíduo”. ${ }^{27}$ A CF não admite, assim, que os direitos e as garantias individuais sejam sacrificados no altar das razões de Estado. O direito extradicional de diferentes Estados com tradição no respeito aos direitos e garantias fundamentais vai nessa mesma linha (LEMONTEY, 1966, p. 54-69).

Pode-se, assim, concluir que o STF exerce um papel de protagonista em um tema importante das relações internacionais do Brasil, especialmente quando ele nega o pedido de extradição. Nesse caso, em nenhuma hipótese, o Presidente da República poderá efetuar a extradição. As ações do Poder Executivo restringem-se a mobilizar o corpo diplomático brasileiro para comunicar oficialmente o Estado requerente sobre a decisão da alta jurisdição brasileira.

O próprio direito extradicional brasileiro desautoriza, pois, a ideia de que o exercício da soberania externa brasileira seria do domínio exclusivo do Presidente da República. O STF, ao não autorizar a extradição, concretiza os valores constitucionais que dão o norte da política externa brasileira e define a conduta a ser posta em prática pelo Estado brasileiro diante de um pedido de um Estado estrangeiro. Em síntese, o STF exerce, também, a soberania externa do Estado brasileiro.

É bem verdade que se o STF deferir o pedido de extradição, caberá ao Presidente da República ter a palavra final sobre o assunto. Foi precisamente esse o sentido do acórdão da Reclamação 11.243. Todavia, isso não invalida, de nenhum modo, o papel determinante que o STF exerce nas relações internacionais do Brasil quando julga improcedente o pedido de extradição.

Por essas razões, parece-nos haver uma incongruência entre o direito extradicional brasileiro e o entendimento de que seriam insidicáveis os atos do Poder Executivo no âmbito das relações internacionais, inclusive no que tange à extradição. Essa observação permanece válida mesmo quando o STF autoriza a extradição, como no caso Battisti. No acórdão da Extradição 1.085, o Supremo deixou claro que o Poder Executivo deveria cumprir o tratado de extradição entre o Brasil e a Itália. Seria, assim, natural que ele seja competente para analisar se, de fato, isso ocorreu, pois tal análise é indispensável para que o STF faça valer o caráter obrigatório de suas decisões.

Os vários motivos invocados para que esse ato do Poder Executivo escape da apreciação jurisdicional não nos parecem convincentes.

Em primeiro lugar, como já visto, o próprio STF faz uso da soberania externa brasileira e encarna a independência nacional no processo de extradição. Tanto um quanto o outro não são atributos exclusivos do Presidente da República. 
Também não nos parece decisivo o fato de ser um Estado estrangeiro que ajuíza a reclamação. Segundo o acórdão da Reclamação 11.243, o Poder Judiciário brasileiro não deve servir para tutelar as pretensões de um Estado estrangeiro. Ora, se as pretensões de um Estado estrangeiro encontram guarida na ordem jurídica brasileira, não há motivos para que o Poder Judiciário se recuse a lhe garantir o exercício de um direito protegido pelo direito brasileiro. Não se pode olvidar que o Poder Judiciário, notadamente o STF, sempre decidirá de acordo com o que diz a Constituição. ${ }^{28} \mathrm{O}$ recurso à justiça não deve ser visto como uma intromissão indevida nos assuntos internos do Estado brasileiro, mas como o regular exercício de um direito assegurado a qualquer pessoa jurídica. Em um Estado de direito, nada mais corriqueiro que uma pessoa jurídica, seja qual for o seu regime jurídico, recorra à Justiça caso entenda que os seus direitos tenham sido lesados. Nem se alegue que isso atenta contra a soberania nacional. O Poder Judiciário é um dos órgãos do Estado brasileiro, isto é, uma das entidades que tomam decisões vinculantes em nome da soberania nacional. Não cabe dizer, assim, que uma decisão do Poder Judiciário em favor de um Estado estrangeiro prejudica a soberania nacional. Seria, ademais, surpreendente que a mais alta corte do país preferisse acórdãos que privilegiassem as nações estrangeiras em detrimento do interesse nacional.

Não nos parece, também, pertinente a assertiva de que o descumprimento de um tratado engendra apenas um litígio entre Estados soberanos, cuja solução é exclusiva de um tribunal internacional. ${ }^{29} \mathrm{O}$ entendimento de que os tratados devidamente ratificados e promulgados fazem parte da ordem jurídica brasileira já se consolidou, de longa data, no STF. Segundo essa leitura, os tratados que não versam sobre direitos humanos ${ }^{30}$ têm status de leis federais ordinárias. Ora, os atos da Presidência da República devem observar o princípio da legalidade, o que inclui os tratados incorporados à ordem jurídica brasileira. Não se pode admitir que a coibição de abusos, contrários à ordem jurídica brasileira e cometidos pelo Presidente da República, fique na dependência de um julgamento de um tribunal internacional.

Isso não quer dizer, naturalmente, que o Poder Executivo deveria ter sido obrigado a extraditar Cesare Battisti. O aspecto que nos parece criticável da decisão do STF na Reclamação 11.243 diz respeito apenas aos seus fundamentos. Havia, sim, substanciais argumentos que referendam a permanência de Battisti em território nacional. Os próprios termos do tratado de extradição entre Brasil e Itália, ao permitir a não extradição caso existam ponderáveis razões para supor o agravamento da situação do extraditando por motivos de sua condição pessoal, permitem justificar essa decisão. As palavras "situação pessoal” e "agravamento da situação" são suficientemente abrangentes para abarcar circunstâncias em que o clamor público prejudica a serenidade necessária para julgamentos de grande conotação política. Poder-se-ia argumentar que o julgamento de Battisti foi envolto por essas circunstâncias. Ademais, no que se refere à execução da pena de Battisti, a atenção política e midiática 
desproporcional que esse caso gerou dá margens ao temor da ausência de equilíbrio das autoridades italianas no cumprimento de sua legislação sobre as execuções penais. Não seria de todo desarrazoado supor que as autoridades italianas tenderiam a ser particularmente rigorosas na aplicação de tal legislação sobre as execuções penais em virtude da situação pessoal de Battisti, notadamente do seu passado político e de seu envolvimento com organizações de extrema esquerda.

Segundo o tratado, a mera suposição é o bastante para que essa exceção seja aplicada. Não há a menor obrigatoriedade de o Estado requerido elencar elementos conclusivos que indiquem uma certeza sobre o agravamento da situação do extraditando. Dado que o tratado de extradição constitui uma limitação da soberania do Estado brasileiro, ele não pode ser interpretado de modo a impor obrigações que vão além do seu texto. ${ }^{31}$

Poder-se-ia, também, afirmar que o Poder Executivo desfruta de uma condição privilegiada para averiguar a existência dessas razões ponderáveis. A embaixada brasileira em Roma e os consultados brasileiros na Itália informam, em primeira mão, o Poder Executivo brasileiro sobre o contexto geral em torno do caso Battisti, seja no que se refere ao julgamento de Battisti já transitado em julgado, seja no tocante às possibilidades de um rigor excessivo na aplicação da pena do extraditando. São os funcionários das embaixadas e dos consulados os agentes do Estado brasileiro que estão em melhores condições para verificar o real estado de coisas na Itália.

A crítica à fundamentação do STF não é destituída de efeitos para a proteção dos direitos humanos em litígios sobre a extradição. Embora essa situação não tenha sido configurada no litígio Battisti, há circunstâncias em que a proteção dos direitos humanos exige que a pessoa reclamada seja extraditada.

Nos julgamentos da Extradição 1.085 e da Reclamação 11.243, ressaltou-se, a justo título, a função de o STF tutelar os direitos e as garantias fundamentais do extraditando e de zelar pela prevalência dos direitos humanos. Com efeito, ao se negar a extraditar estrangeiros por crimes políticos ou para Estados autoritários, a alta jurisdição brasileira cumpre indubitavelmente esse papel.

Todavia, quando o extraditando é acusado de graves violações aos direitos humanos e o Estado requerente respeita as garantias do devido processo legal, o princípio constitucional da prevalência dos direitos humanos impõe a extradição da pessoa reclamada.

No direito público atual, tratados sobre direitos humanos impõem obrigações em matéria de extradição para evitar a impunidade dos autores dos piores crimes contra a dignidade humana. Exemplo disso é a Convenção de 1984 contra a Tortura e Outros Tratamentos ou Penas Cruéis, Desumanos ou Degradantes. ${ }^{32} \mathrm{O}$ preâmbulo desse tratado estabelece a finalidade de "tornar mais eficaz a luta contra a tortura e outros tratamentos ou penas cruéis, desumanos ou degradantes em todo mundo”.

Foi essa convenção de grande importância que conduziu a Câmara dos Lordes inglesa a colocar em causa uma norma clássica de direito internacional público: a imunidade 
de jurisdição dos ex-governantes. Quando houve o pedido espanhol ao Reino Unido de extradição de Augusto Pinochet, invocou-se a sua condição de ex-chefe de Estado para afirmar que o pedido deveria ser negado. Segundo o direito internacional público clássico, os atos praticados pelo ex-ditador chileno são atos de função que estariam subtraídos da apreciação de uma jurisdição estrangeira. Embora a Câmara dos Lordes tenha reconhecido a vigência desse preceito, ela estabeleceu limites ao seu alcance. Para a alta jurisdição inglesa, a Convenção contra a tortura de 1984, de que o Chile e o Reino Unido são partes, instituiu um sistema internacional para combatê-la. Assim, prosseguiram os Lordes, podia-se depreender de tal sistema convencional uma exceção, se bem que implícita, à imunidade dos ex-chefes de Estado quando eles são acusados de haver cometido o crime de tortura. Concluir de outro modo seria, nessa linha de pensamento, contraditório com a finalidade mesma desse tratado: a repressão à tortura. Com base nessas ponderações, a Câmara dos Lordes autorizou a extradição de Augusto Pinochet para a Espanha. ${ }^{33}$

Recentemente, a Corte Internacional de Justiça (CIJ) interpretou as disposições dessa mesma convenção no litígio que opôs a Bélgica ao Senegal. Em janeiro de 2009, a Bélgica depositou uma reclamação na CIJ contra o Senegal alegando que este havia violado tal convenção ao se recusar, ao mesmo tempo, a processar criminalmente Hissène Habré e a extraditá-lo para a Bélgica. O ex-presidente do Tchad, o qual havia se exilado no Senegal, era acusado de ter cometido crimes de tortura e outras violações graves do direito internacional humanitário durante os oito anos em que esteve no poder. Segundo a CIJ, a convenção prescreve a obrigação, para o Estado em cujo território se encontra o autor presumido do crime de tortura, de processá-lo criminalmente ou de extraditá-lo. Portanto, segundo a CIJ, se o Senegal não processar criminalmente Habré, ele tem a obrigação convencional de extraditá-lo para a Bélgica, pois esse país requereu a sua extradição com base em sua célebre lei sobre a competência universal. Para a CIJ, todos os Estados-partes da aludida Convenção têm um interesse comum em assegurar a prevenção da tortura e zelar para que os autores desse crime não se beneficiem da impunidade. ${ }^{34}$

Outros tratados de proteção dos direitos humanos estabelecem disposições similares sobre esse tema, como as Convenções de Genebra de $1949^{35}$ e a Convenção da ONU para a Proteção de Todas as Pessoas contra o Desparecimento Forçado. ${ }^{36}$ Tais disposições estabelecem uma obrigação alternativa aos Estados-partes: ou processam eles próprios os indivíduos que se encontram em seu território e que são acusados de crimes contra os direitos humanos ou eles devem extraditá-los para os Estados que efetuem tal pedido. Essa obrigação, conhecida pela expressão latina aut dedere aut judicaire, tem o nítido propósito de evitar a impunidade em relação aos piores crimes cometidos contra os direitos humanos.

A Corte Interamericana de Direitos Humanos (CIDH) identificou, também, obrigações em matéria de extradição nos tratados sobre direitos humanos. No caso Goiburú, 
a CIDH censurou o Paraguai por não ter investigado devidamente as violações aos direitos humanos e sancionado os responsáveis por tais violações cometidas sob o regime ditatorial de Alfredo Stroessner (1954-1989), haja vista que o Estado paraguaio jamais efetivou o pedido ao Brasil de extradição do ex-chefe de Estado paraguaio. A Corte foi mais além: há, em virtude da CIDH, a obrigação de os Estados cooperarem entre si, para que a impunidade dos autores de graves crimes contra os direitos humanos seja erradicada. Desse modo, nenhum Estado deve outorgar proteção a tais autores. Por conseguinte, os Estados-partes devem ou julgar, eles próprios, tais autores ou extraditá-los. ${ }^{37}$

Esses exemplos demonstram a clara tendência do direito internacional atual em impor obrigações aos Estados, inclusive em matéria de extradição, para impedir que os autores dos piores crimes contra a dignidade humana encontrem um refúgio em algum Estado e escapem, assim, da justiça.

Em síntese, fazer prevalecer os direitos humanos nas relações internacionais não significa apenas se negar a extraditar, quando o extraditando responde por crimes políticos ou, então, quando o Estado requerente não observa direitos básicos do acusado, como a ampla defesa. Fazer prevalecer os direitos humanos nas relações internacionais significa, também, aceitar o pedido de extradição de Estados que respeitem o devido processo legal, quando se trata de autores de graves crimes internacionais, a exemplo do genocídio e da tortura.

Se os fundamentos utilizados no caso Battisti pelo STF forem levados às últimas consequências, eles impedem que se questione judicialmente uma eventual decisão do Presidente da República negando a extradição de um autor de graves violações aos direitos humanos. Com efeito, segundo o Supremo, o ato de recusa do Presidente da República em extraditar não está submetido a nenhum tipo de controle jurisdicional. Essa leitura acorda ao Presidente da República a mais ampla liberdade para repudiar o princípio constitucional da prevalência dos direitos humanos nas relações internacionais do Brasil, caso o Presidente da República se negue a extraditar um acusado de graves crimes contra os direitos humanos a um Estado que conduz os seus processos penais segundo os cânones do devido processo legal.

\section{CONCLUSÃo}

Uma das mais extraordinárias evoluções do direito público contemporâneo foi a consolidação da ideia de que os detentores do poder devem ser vigiados e devem exercer as suas atribuições públicas de acordo com a lei, e não segundo os seus caprichos e as suas instáveis vontades. Como bem salientou Elisabeth Zoller, no direito público comparado, esses progressos ocorreram com um rigor muito maior nos atos do Estado voltados para dentro que nas condutas do Estado dirigidas ao estrangeiro (ZOLLER, 1992, p. 167). 
Esse estado de coisas, contudo, não nos parece mais conforme ao texto constitucional brasileiro. Tornou-se lugar comum realçar, a justo título, a contribuição da CF para restabelecer o Estado de direito. Em um momento que os atos de soberania externa brasileira assumem especial relevo em virtude da interpenetração entre a política interna e a política externa, é preciso reforçar a obrigatoriedade desse princípio no direito brasileiro das relações exteriores. É por esse motivo que a decisão do STF que afirmou o caráter insidicável dos atos do Presidente da República na disposição da soberania externa brasileira nos parece ser um retrocesso.

É certo que o Estado brasileiro deve conduzir as suas relações com os seus pares na comunidade internacional com total autonomia, sem estar obrigado a seguir as orientações de qualquer outro Estado estrangeiro. Como ressaltou a CIJ no emblemático caso Nicarágua contra Estados Unidos, a liberdade de que os Estados dispõem em política externa deriva da sua soberania. ${ }^{38}$ Defender essa autonomia do Estado brasileiro é, no entanto, algo inteiramente diverso do que propugnar pela ausência de controles de direito público interno dos atos do Poder Executivo nessa seara.

O direito público brasileiro impõe um conjunto substantivo de normas jurídicas que obrigam os diferentes órgãos do Estado brasileiro a pautarem as relações exteriores do Brasil por certos princípios. Tais normas disciplinam as relações do Estado brasileiro com os outros sujeitos de direito internacional. Daí a importância do controle jurisidicional da política externa para que tais regras sejam efetivamente cumpridas.

: ARTIGO APROVADO (19/03/2014) : RECEBIDO EM 04/02/2013

\section{NOTAS}

1 Veja-se, por exemplo, PASCHOAL, Janaína Conceição. Acolher Battisti não é escolha jurídica. Folha de S.Paulo, 13 de setembro de 2010, p. A-3; e BARROSO, Luis Roberto. O último perseguido. Disponível em: <http://www.lrbarroso.com.br/shared/download/casos-cesare-battisti-artigo-ultimo-perseguido.pdf >. Acesso em: 12 dez. 2012. Vejam-se, também, os pareceres de José Afonso da Silva e de Celso Antônio Bandeira de Mello sobre a constitucionalidade do status de refugiado concedido a Cesare Battisti. Disponíveis, respectivamente, em: $<$ http://www.oab.org.br/noticia/16483/jose-afonso-conclui-que-concessao-de-refugio-a-battisti-e-constitucional $>$ e <http://www.migalhas.com.br/Quentes/17,MI93573,71043-Parecer+do+professor+Celso+Antonio+Bandeira+de+ Mello+sobre+o+caso>. Acesso em: 14 dez. 2012.

2 Supremo Tribunal Federal, Extradição 1.085. Rel. Min. Cezar Peluso. Disponível em: <www.stf.jus.br>. Acesso em: $1^{\circ}$ dez. 2012 
3 Supremo Tribunal Federal, Reclamação 11.243. Rel. Min. Gilmar Mendes. Disponível em: <www.stf.jus.br>. Acesso em: $1^{\circ}$ dez. 2012.

4 Segundo o art. 29 da Lei n. 9.474/97 - lei que define no direito brasileiro mecanismos para a implementação do Estatuto dos Refugiados de 1951 -, no caso de decisão negativa do Conare sobre o pedido da concessão do refúgio, cabe recurso direito ao Ministro de Estado da Justiça.

5 Segundo o art. $1^{\circ}$ da Lei n. 9.474/97: “Art. $1^{\circ}$ Será reconhecido como refugiado todo indivíduo que: I - devido a fundados temores de perseguição por motivos de raça, religião, nacionalidade, grupo social ou opiniões políticas encontre-se fora de seu país de nacionalidade e não possa ou não queira acolher-se à proteção de tal país; [...]”.

6 A decisão do Presidente da República foi publicada no Diário Oficial da União em 31 de dezembro de 2010.

7 Os textos do parecer e do despacho do Advogado-Geral da União Substituto encontram-se disponíveis em: $<$ http: / /www.agu.gov.br/sistemas/site/TemplateImagemTextoThumb.aspx?idConteudo=155567\&id_site=3>. Acesso em: $1^{\circ}$ dez. 2012.

8 Cabe lembrar o que dispõe o artigo 84, II: “Art. 84. Compete privativamente ao Presidente da República: [...] II - exercer, com o auxílio dos Ministros de Estado, a direção superior da administração federal”.

9 O Decreto n. 70.274, de 9 de março de 1972 - o qual aprova as normas de cerimonial público e a ordem geral de precedência -, disciplina minuciosamente o cerimonial extremamente formal em que ocorre essa entrega. Sobre o simbolismo de que se reveste a entrega dessas credenciais no direito português, v. Araújo (2010).

10 Sob esse ponto de vista, há uma notável homologia entre o artigo 14 da Constituição francesa e o artigo 84, IV, da Constituição brasileira. Sobre o significado do artigo 14 da Constituição francesa, v. notadamente Zoller (1992, p. 68).

11 Pode-se citar, a título ilustrativo, o impacto humano e econômico para um Estado que realiza operações armadas no estrangeiro: a perda de vidas humanas de seus militares e os custos econômicos substanciais decorrentes da mobilização de suas forças armadas.

12 Para um estudo bem completo sobre os diferentes mecanismos de controle da política externa brasileira, v. especialmente Sanchez; Silva; Cardoso; Specie (2006, p. 125-143).

13 Em um célebre dictum no caso Wimbledon, a Corte permanente de Justiça internacional afirmou: "A Corte recusa-se a ver na conclusão de um tratado qualquer, por meio do qual um Estado se obriga a fazer ou a não fazer algo, um abandono de sua soberania. Sem dúvida, toda convenção que engendra uma obrigação desse tipo traz uma restrição ao exercício dos direitos soberanos do Estado, no sentido de que ela imprime a esse exercício uma direção determinada. Mas a faculdade de contratar esses compromissos internacionais é precisamente um atributo da soberania do Estado" (tradução livre do autor da versão original em francês). Corte Permanente de Justiça Internacional, Vapeur Wimbledon. Acórdão de 17 de agosto de 1923. Disponível em: <www.icj-cij.org>. Acesso em: $1^{\circ}$ nov. 2012. Deveras, a capacidade de ratificar tratados internacionais é um dos atributos da soberania do Estado, sujeito por excelência de direito internacional público. Nesse sentido, o artigo $6^{\circ}$ da Convenção de Viena sobre o direito dos tratados preceitua que todo Estado tem capacidade para concluir tratados.

14 V., respectivamente, os Decretos Legislativos n. 5/99 e 207/2004.

15 Supremo Tribunal Federal, Ação Direta de Inconstitucionalidade 1.480-3. Rel. Min. Celso de Mello. Disponível em: <www.stf.jus.br>. Acesso em: 10 dez. 2000.

16 Cumpre ressalvar que não conseguimos obter o inteiro teor dos votos dos ministros nesse litígio no site do STF, à exceção do voto do Ministro Joaquim Barbosa. As observações acima sobre os votos dos ministros baseiam-se em informativos disponíveis no mencionado site. Disponível em: <www.stf.jus.br>. Acesso em: 1º dez. 2012.

17 Supremo Tribunal Federal, Arguição de Descumprimento de Preceito Fundamental 172-2. Rel. Min. Marco Aurélio. Disponível em: <www.stf.jus.br>. Acesso em: 5 dez. 2012. 
18 Veja-se, por exemplo, o Recurso Extraordinário 222.368-Agr, em que o STF entendeu que as imunidades diplomáticas das representações estrangeiras do Brasil eram relativas e não abrangiam os processos trabalhistas. Supremo Tribunal Federal, Recurso Extraordinário 222.368-Agr. Rel. Min. Celso de Mello. Disponível em: <www.stf.jus.br>. Acesso em: $1^{\circ}$ nov. 2012.

19 Sobre o assunto, v. também Flinterman (1995, p. 45-54); e Sumption, disponível em: <http://www. supremecourt. gov.uk/docs/speech_120514.pdf>. Acesso em: 15 jan. 2013.

20 Essa estreita relação já foi abundantemente salientada pela doutrina. O caráter relativo da noção de assuntos internos e do domínio reservado dos Estados no direito das organizações internacionais é disso uma ilustração. V., por exemplo, Trindade (2003, especialmente p. 90-152).

21 Vejam-se, a esse respeito: Corte Interamericana de Direitos Humanos, Restricciones a la pena de muerte (arts. 4.2 y 4.4. Convención americana sobre derechos humanos). Opinião Consultiva de 8 de setembro de $1983, \S 50$. Disponível em: <http://www.corteidh.or.cr/>. Acesso em: $1^{\circ}$ fev. 2012.

22 Supremo Tribunal Federal, Extradição 1.085, p. 245. Essa definição é clássica e é adotada por diferentes autores com pequenas modificações de formulação. Por exemplo, no Dicionário de direito internacional, de Jean Salmon, a extradição é definida do mesmo modo (SALMON, 2001, p. 489). Para uma definição similar de extradição, v. também Chauvy (1981, p. 3-4).

23 É bem verdade que há casos célebres em que esse fato ocorreu, como a captura de Einchman pelo serviço secreto israelense em território argentino sem que o Estado argentino tenha dado o seu consentimento. Tais casos constituem, todavia, uma violação do direito internacional, mais precisamente do respeito à soberania territorial dos Estados. Sobre o assunto, v. Green (1963, p. 150-190).

24 No mesmo sentido, a Corte Internacional de Justiça, no caso Haya de la Torre, ressaltou: "No caso da extradição, o refugiado se encontra no território do Estado de refúgio. Uma decisão relativa à extradição implica apenas o exercício normal da soberania territorial. O refugiado se encontra fora do território do Estado onde o delito foi cometido e uma decisão de lhe acordar o asilo não derroga, de nenhum modo, a soberania desse Estado" (tradução livre do autor do texto original em francês). Corte Internacional de Justiça. Affaire colombo-péruvienne relative au droit d'asile. Acórdão de 20 de novembro de 1950, p. 274. Disponível em: <http://www.icj-cij.org>. Acesso em: $1^{\circ}$ dez. 2012. Sobre o assunto, v. também Souza (1998, p. 39).

25 Supremo Tribunal Federal, Extradição 633-9. Rel. Min. Celso de Mello. Disponível em: <www.stf.jus.br>. Acesso em $4^{\circ}$ dez. 2012.

26 Nesse sentido, o artigo $5^{\circ}, \mathrm{LXI}$, da CF prescreve: "ninguém será preso senão em flagrante delito ou por ordem escrita e fundamentada de autoridade judiciária competente, salvo nos casos de transgressão militar ou crime propriamente militar, definidos em lei”. Sobre o assunto, v. também Rezek (1976, p. 240).

27 Supremo Tribunal Federal, Reclamação 11.243, p. 127.

28 Em matéria de direito internacional, o STF não hesitou em declarar inconstitucionais tratados devidamente ratificados pelo Brasil e que, portanto, criam obrigações internacionais para o Brasil. O motivo invocado pelo STF foi justamente o seu papel de guardião da Constituição Federal. Há, assim, uma clara preocupação do STF em privilegiar o cumprimento da Constituição em detrimento das obrigações internacionais que o Brasil assumiu perante a comunidade internacional. Sobre esse assunto, v. o item 1 supra.

29 Foi essa a linha da argumentação do acórdão do STF na Reclamação 11.243: "10. O descumprimento do Tratado, em tese, gera uma lide entre Estados soberanos, cuja resolução não compete ao Supremo Tribunal Federal, que não exerce soberania internacional, máxime para impor a vontade da República Italiana ao Chefe de Estado brasileiro, cogitando-se de mediação da Corte Internacional de Haia, nos termos do art. 92 da Carta das Nações Unidas de 1945”.

30 Em relação aos tratados sobre direitos humanos, há ainda uma grande controvérsia sobre o seu status normativo. Sobre o assunto, v. Del'olmo (2007, p. 234). 
31 É conhecido o princípio em matéria de interpretação de tratados de que as limitações da soberania não se presumem. Sobre as regras que regem a interpretação dos tratados internacionais, v. Sorel (2006, p. 1289-1334).

32 Essa convenção foi internalizada no ordenamento jurídico brasileiro pelo Decreto n. 40, de 15 de fevereiro de 1991.

33 Vejam-se, a esse respeito, especialmente os votos de Lord Browne-Wilkinson, Lord Hutton, Lord Millet, Lord Saville of Newdigate, Lord Philips of Worth Matravers. House of Lords, Judgment - Regina v. Bartle and the Commissioner of Police for the Metropolis and Others Ex Parte Pinochet Regina v. Evans and Another and the Commissioner of Police for the Metropolis and Others Ex Parte Pinochet (On Appeal from a Divisional Court of the Queen's Bench Division). Decisão de 24 de março de 1999. International Legal Materials, v. 38, 1999, p. 591-663.

34 Corte Internacional de Justiça. Questions concernant l'obligation de porsuivre ou d'extrader (Belgique c.

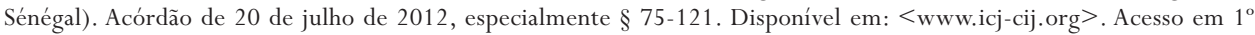
nov. 2012. Sobre o assunto, ver também GALICKI, Zdzislaw. Rapport préliminaire sur l'obligation d'extrader ou de poursuivre («aut dedere aut punire»). Relatório apresentado à Comissão de Direito Internacional da ONU, A/CN.4/571.

35 As Convenções de Genebra de 1949 constituem o núcleo do direito internacional humanitário: a Convenção para a Melhoria da Sorte dos Feridos e Enfermos em Exércitos em Campanha (I); a Convenção para a Melhoria da Sorte dos Feridos, Enfermos e Náufragos das Forças Armadas no Mar (II); a Convenção Relativa ao Tratamento dos Prisioneiros de Guerra (III); e a Convenção Relativa à Proteção dos Civis em Tempo de Guerra (IV). Essas convenções foram ratificadas pelo Brasil e promulgadas pelo Decreto n. 42.121, de 21 de agosto de 1957. Veja-se, por exemplo, o artigo 69 da Convenção de Genebra I.

36 Essa Convenção foi ratificada pelo Brasil em 29 de novembro de 2010. Veja-se, especialmente, o seu artigo 11.

37 Corte Interamericana de Direitos Humanos, Caso Goiburú y otros vs. Paraguay, sentença de 22 de setembro de $2006, \S 123-132$.

38 Corte Internacional de Justiça, Affaire des activités militaires et paramilitaires au Nicaragua et contre celui-ci (Nicaragua c. États-Unis d'Amérique). Acórdão de 27 de junho de 1986, § 265. Disponível em: <http://www.icj-cij.org/> . Acesso em: $1^{\circ}$ jun. 2012.

\section{REFERÊNCIAS BIBLIOGRÁFICAS}

\section{Livros}

ARON, Raymond. Paz e guerra entre as nações. Brasília: Ed. UnB, 2002.

CHAUVY, Yves. L'extradition. Paris: Presses Universitaires de France, 1981.

DEL'OLMO, Florisbal de Souza. A extradição no alvorecer do século XXI. Rio de Janeiro: Renovar, 2007.

LEMONTEY, Jacques. Du rôle de l'autorité judiciaire dans la procédure d'extradition passive. Paris: L.G.D.J., 1966.

REZEK, José Francisco. Direito dos tratados. Rio de Janeiro: Forense, 1984.

RUSSOMANO, Gilda Maciel Corrêa Meyer. A extradição no direito internacional e no brasileiro. São Paulo: Revista dos Tribunais, 1981.

SALMON, Jean (sous la direction de). Dictionnaire de droit international public. Bruxelles: Bruylant, 2001.

SOUZA, Arthur de Brito Gueiros. As novas tendências do direito extradicional. Rio de Janeiro: Renovar, 1998.

TRINDADE, Antônio Augusto Cançado. Direito das organizações internacionais. 3. ed. Belo Horizonte: Del Rey, 2003.

ZOLLER, Elisabeth. Droit des relations extérieures. Paris: PUF, 1992.

\section{Artigos}

ARAÚJO, Antônio de. Função presidencial e política externa. Relações internacionais, n. 28, dez. 2010. Disponível em: <http://www.scielo.oces.mctes.pt/scielo.php?pid=S1645-91992010000400005\&script=sci_arttext $>$. Acesso em: 10 jan. 2012. 
BADIN, Michelle Ratton Sanchez; FRANÇA, Cássio Luiz de. A inserção internacional do poder executivo federal brasileiro. Friedrich-Ebert-Stiftung, São Paulo, n. 40, ago. 2010.

BARROSO, Luis Roberto. O último perseguido. Disponível em: <http://www.lrbarroso.com.br/shared/ download/casos-cesare-battisti-artigo-ultimo-perseguido.pdf> . Acesso em: 12 dez. 2012.

BONICHOT, Jean-Claude. L'évolution récente de l'extradition passive en France. Annuaire Français de Droit International, v. 30, p. 19-42, 1984.

FLINTERMAN, Cees. Judicial control of foreign affairs: the political question doctrine. In: BAKKER, R.; HERINGA, A. W.; STROIK, F. Judicial control: comparative essays on judicial review. Malku: Antwerpeen, 1995, p. 45-54.

GALICKI, Zdzislaw. Rapport préliminaire sur l'obligation d'extrader ou de poursuivre («aut dedere aut punire»). Relatório apresentado à Comissão de Direito Internacional da ONU, A/CN.4/571.

GREEN, Leslie. Aspects juridiques du procès Eichman. Annuaire français de droit international, v. 9, n. 9, p. $150-190,1963$.

MELLO, Celso Antônio Bandeira de. Parecer sobre o caso Cesare Battisti. Parecer disponível em:

$<$ http://www.migalhas.com.br/Quentes/17, MI93573,71043-

Parecer+do+professor+Celso+Antonio+Bandeira+de+Mello+sobre+o+caso >. Acesso em: 14 dez. 2012.

PASCHOAL, Janaína Conceição. Acolher Battisti não é escolha jurídica. Folha de S.Paulo, 13 de setembro de 2010 , p. A-3

REZEK, José Francisco. Perspectiva do regime jurídico da extradição. Estudos de direito público em homenagem a Aliomar Baleeiro. Brasília: Editora UnB, p. 233-264, 1976.

RICHARD, Philippe. Droit de l'extradition et terrorisme. Risques d'une pratique incertaine: du droit vers le non-droit. Annuaire français de droit international, v. 34, n. 34, p. 652-676, 1988.

SANCHEZ, Michelle Ratton; SILVA, Elaini C. G. da; CARDOSO, Evorah L.; SPECIE, Priscila. Política externa como política pública: uma análise pela regulamentação constitucional brasileira (1967-1898). Revista de Sociologia e Política, n. 27, p. 125-143, 2006.

SOREL, Jean-Marc. L'article 31. In: CORTEN, Olivier; KLEIN, Pierre. Les conventions de Vienne sur le droit des traités: commentaire article par article. Bruxelles: Bruylant, 2006.

SILVA, José Afonso da. Pedido de análise da situação do italiano Cesare Battisti preso no Brasil e a legalidade da decisão do Ministro da Justiça. Parecer disponível em: <http://www.oab.org.br/noticia/16483/jose-afonsoconclui-que-concessao-de-refugio-a-battisti-e-constitucional>. Acesso em: 14 dez. 2012.

SUMPTION, Jonathan. Foreign affairs in the English Courts since 9/11. Lecture at the Department of Government, London School of Economics. Disponível em: <http://www.supremecourt.gov.uk/docs/ speech_120514.pdf>. Acesso em: 15 jan. 2013.

\section{Jurisprudência}

Corte Interamericana de Direitos Humanos, Restricciones a la pena de muerte (arts. 4.2 y 4.4 Convención americana sobre derechos humanos). Opinião Consultiva de 8 de setembro de 1983, §50. Disponível em: <http://www.corteidh.or.cr/>. Acesso em: $1^{\circ}$ fev. 2012.

Corte Internacional de Justiça, Affaire colombo-péruvienne relative au droit d'asile. Acórdão de 20 de novembro

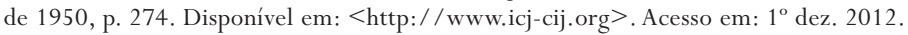

Corte Internacional de Justiça, Affaire des activités militaires et paramilitaires au Nicaragua et contre celui-ci (Nicaragua c. États-Unis d'Amérique). Acórdão de 27 de junho de 1986, § 265. Disponível em:

<http://www.icj-cij.org/>. Acesso em: $1^{\circ}$ jun. 2012.

Corte Internacional de Justiça, Questions concernant l'obligation de porsuivre ou d'extrader (Belgique c. Sénégal). Acórdão de 20 de julho de 2012. Disponível em: <www.icj-cij.org>. Acesso em $1^{\circ}$ nov. 2012. Corte Permanente de Justiça Internacional, Vapeur Wimbledon. Acórdão de 17 de agosto de 1923. Disponível em: <www.icj-cij.org>. Acesso em: $1^{\circ}$ nov. 2012.

House of Lords, Judgment - Regina v. Bartle and the Commissioner of Police for the Metropolis and Others Ex Parte Pinochet Regina v. Evans and Another and the Commissioner of Police for the Metropolis and Others Ex Parte Pinochet (On Appeal from a Divisional Court of the Queen's Bench Division). Decisão de 24 de março de 1999. International Legal Materials, v. 38, p. 591-663, 1999.

Supremo Tribunal Federal, Ação Direta de Inconstitucionalidade 1.480-3. Rel. Min. Celso de Mello. Disponível em: <www.stf.jus.br>. Acesso em: 10 dez. 2013.

Supremo Tribunal Federal, Arguição de Descumprimento de Preceito Fundamental 172-2. Rel. Min. Marco Aurélio. Disponível em: <www.stf.jus.br>. Acesso em: 5 dez. 2012.

Supremo Tribunal Federal, Extradição 633-9. Rel. Min. Celso de Mello. Disponível em: <www.stf.jus.br>. Acesso em $4^{\circ}$ dez. 2012. 
Supremo Tribunal Federal, Extradição 1.085. Rel. Min. Cezar Peluso. Disponível em: <ww.stf.jus.br>. Acesso em: $1^{\circ}$ dez. 2012.

Supremo Tribunal Federal, Reclamação 11.243. Rel. Min. Gilmar Mendes. Disponível em: <ww.stf.jus.br>. Acesso em: $1^{\circ}$ dez. 2012.

Supremo Tribunal Federal, Recurso Extraordinário 222.368-Agr. Rel. Min. Celso de Mello. Disponível em:

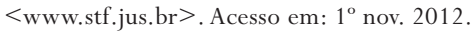

Daniel Damásio Borges

Faculdade de Ciências Humanas e Sociais - UNESP Departamento de Direito Público - Campus de Franca Av. Eufrásia Monteiro Petráglia, 900 Jd. Dr. Antonio Petráglia - 14409-160 Franca - SP - Brasil dadblauol.com.br
DOUTOR EM DIREITO PELA UNIVERSIDADE PARIS I PROFESSOR ASSISTENTE DOUTOR DE DIREITO INTERNACIONAL da Faculdade de Clências Humanas E SOCIAIS DA UNESP - CAMPUS DE FRANCA 